Ideas and Welfare State Reform in Western Europe 
Also by Peter Taylor-Gooby:

CHOICE AND PUBLIC POLICY: THE LIMITS TO WELFARE MARKETS (editor) EUROPEAN WELFARE FUTURES (with V. George and G. Bonoli)

EUROPEAN WELFARE POLICY: SQUARING THE WELFARE CIRCLE (edited, with V. George)

EUROPEAN WELFARE STATES UNDER PRESSURE (edited)

MAKING A EUROPEAN WELFARE STATE? CONVERGENCES AND CONFLICTS OVER EUROPEAN SOCIAL POLICY (edited)

NEW RISKS, NEW WELFARE: THE TRANSFORMATION OF THE EUROPEAN

WELFARE STATE (edited)

RISK, TRUST AND WELFARE (edited)

THE END OF THE WELFARE STATE? RESPONSES TO RETRENCHMENT (edited, with S. Svallfors) 


\section{Ideas and Welfare State Reform in Western Europe}

edited by

Peter Taylor-Gooby, Professor of Social Policy,

University of Kent 


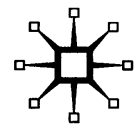

Editorial Matter \& Selection, Chapter 1 \& Chapter 2 (c) Peter Taylor-Gooby 2005

Chapter 3 C Virpi Timonen 2005

Chapter 4 C Trine P Larsen 2005

Chapter 5 (C) Frank Bönker 2005

Chapter 6 (C) Andreas Aust \& Ana Arriba 2005

Chapter 7 (C) Johannes Kananen 2005

Chapter 8 C Luis Moreno \& Bruno Palier 2005

Softcover reprint of the hardcover 1st edition 2005 978-1-4039-9317-5

All rights reserved. No reproduction, copy or transmission of this publication may be made without written permission.

No paragraph of this publication may be reproduced, copied or transmitted save with written permission or in accordance with the provisions of the Copyright, Designs and Patents Act 1988, or under the terms of any licence permitting limited copying issued by the Copyright Licensing Agency, 90 Tottenham Court Road, London W1T 4LP.

Any person who does any unauthorised act in relation to this publication may be liable to criminal prosecution and civil claims for damages.

The authors have asserted their rights to be identified as the authors of this work in accordance with the Copyright, Designs and Patents Act 1988.

First published 2005 by

PALGRAVE MACMILLAN

Houndmills, Basingstoke, Hampshire RG21 6XS and

175 Fifth Avenue, New York, N. Y. 10010

Companies and representatives throughout the world

PALGRAVE MACMILLAN is the global academic imprint of the Palgrave Macmillan division of St. Martin's Press, LLC and of Palgrave Macmillan Ltd. Macmillan ${ }^{\circledR}$ is a registered trademark in the United States, United Kingdom and other countries. Palgrave is a registered trademark in the European Union and other countries.

ISBN 978-1-349-54387-8 ISBN 978-0-230-28601-6 (eBook)
DOI 10.1057/9780230286016

This book is printed on paper suitable for recycling and made from fully managed and sustained forest sources.

A catalogue record for this book is available from the British Library.

Library of Congress Cataloging-in-Publication Data

Ideas and welfare state reform in Western Europe / edited by Peter Taylor-Gooby.

p. cm.

Includes bibliographical references and index.

1. Europe-Social policy. 2. Public welfare-Europe. 3. Welfare state-Europe. I. Taylor-Gooby, Peter.

HN373.5+

361.6'8'094-dc22

$\begin{array}{llllllllll}10 & 9 & 8 & 7 & 6 & 5 & 4 & 3 & 2 & 1\end{array}$

$\begin{array}{llllllllll}14 & 13 & 12 & 11 & 10 & 09 & 08 & 07 & 06 & 05\end{array}$ 


\section{Contents}

List of Tables viii

List of Figures ix

Acknowledgements $\quad$ x

Preface $\quad$ xi

Notes on the Contributors xiii

1 Ideas and Policy Change 1

Peter Taylor-Gooby

The growing prominence of ideas 1

Ideas and social actions 3

$\begin{array}{ll}\text { Paradigm, discourse and political actors } & 7\end{array}$

The plan of the book $\quad 8$

2 Paradigm Shifts, Power Resources and Labour Market

Reform

Peter Taylor-Gooby

Germany: labour market policy 12

Labour market policy in France 18

Labour market policy in the UK 22

Discourse: a facilitator of paradigm shift in the context of power resources 26

3 Policy Paradigms and Long-Term Care: Convergence or Continuing Difference? 30

Virpi Timonen

Introduction $\quad 30$

Identifying policy paradigms in long-term care $\quad 30$

Analytical tools 31

Three long-term care policy paradigms $\quad 32$

Have the paradigms evolved significantly? 34

Summary of paradigm change 39

What explains the change or lack of change in the paradigms? 
Are the paradigms converging?

Are there some 'common themes' that the paradigms

share?

Conclusion

4 The Myth of an Adult Worker Society: New Policy

Discourses in European Welfare States

Trine P. Larsen

Introduction

The female workforce and national welfare settlements

Changing national policy discourses

Recent national policy reforms

Agenda one: work family life reforms

Second political agenda: equal opportunities policies

Conclusion

5 Changing Ideas on Pensions: Accounting for Differences in the Spread of the Multipillar Paradigm in Five EU Social Insurance Countries

Frank Bönker

Introduction

Competing policy paradigms in pension policy

Differences in the spread of the multipillar paradigm

Accounting for differences in the spread of the multipillar paradigm

Summary and outlook

6 Towards Activation? Social Assistance Reforms and Discourses

Andreas Aust and Ana Arriba

Introduction

Social assistance schemes

The changing role of social assistance in the era of mass unemployment

Major reforms

Ideas, discourses and social assistance reforms in the 1990s 
7 Current Employment Policy Paradigms in the UK, Sweden and Germany

Johannes Kananen

Policy paradigms as ideal types

UK

Sweden

Germany

Conclusions

8 The Europeanisation of Welfare: Paradigm Shifts and Social Policy Reforms

Luis Moreno and Bruno Palier

1. Introduction: concepts and premises

2. Continuity and change in European welfare development

3. EU, an instigator for social policy reform

4. Economic-social and national-EU dichotomies

5. Conclusion 


\section{List of Tables}

Table 2.1 Spending on labour market programmes

(\% GDP)

Table 2.2 Growth and unemployment (\%)

Table 3.1 Summary of the old and new policy features and main factors shaping long-term care policy in the five countries

Table 4.1 Work/family reforms in Germany, Sweden, Spain and the UK and their effect on female employment

Table 5.1 The importance of different pillars of retirement income

Table 6.1 Social assistance schemes

Table 6.2 Policy reforms in social assistance schemes in the 1990s

Table 6.3 Discourses of social exclusion

Table 7.1 Three employment policy paradigms

Table 7.2 Current employment policy paradigms in the UK, Sweden and Germany 


\section{List of Figures}

Figure 4.1 Gender and labour market participation for women and men, participation of those aged $15-64$ as per cent of relevant population 


\section{Acknowledgements}

We would like to express our thanks to the EU for FPV Project Grant no 20000-00054 (2001-5), which made the work possible. 


\section{Preface}

The future of the welfare state is at the centre of European political debate. On the one hand, critics argue that the concept of state responsibility for the welfare of citizens is obsolete. Globalisation makes the traditional ideal of the neo-Keynesian interventionist government, unquestioned authority in its own territory, outdated; high levels of public spending undermine individual responsibility and damage the competitiveness of the economy; people are increasingly reluctant to accept the judgements of experts and officials and keen to pursue their own welfare as they see it.

On the other hand, the welfare state is widely seen as a European invention, a distinctive solution to the problem of balancing economic progress and social justice within a polity. Active state support is seen as an essential ingredient in success in the new knowledge-based economy. The role of government in citizen welfare is being rethought across Europe, and the EU is seeking to take the lead in the coordination of new approaches to welfare.

These developments focus attention on the role of ideas in policy making and debate, in policy learning and transfer, in negotiation and in the construction of compromise between political actors, and, more broadly, in attracting the support of the constituencies of voters and citizens on whose endorsement the actors depend. This book examines the role of ideas in welfare state reform in Europe. It seeks to distinguish the respective contribution of ideas and of practical factors - economic change and political realignment - in the new European welfare settlement.

Our work draws on the data gathered by a major EU Framework Five research project: Welfare Reform and the Management of Societal Change. We are grateful for the support which made our collaboration possible. The arguments presented here were developed through discussion at a series of conferences in Canterbury, Paris, Madrid, Berlin and Oxford, and via email. We would like particularly to thank the discussants at our Berlin conference: Jochen Clasen, Valerie Fargion, Peter Flora, Peter Hall, Michael Hill, Ellen Immergut, Stephan Lessenich, Jane Lewis, August Oesterle, Claus Offe and Paul Pierson, for their suggestions and encouragement. 


\section{xii Preface}

We also benefited from the generous advice and guidance of Professor Karl Hinrichs, our academic adviser, and from the comments of Professor Vivien Schmidt, and many others. Members of the group who are not named as chapter authors, but who nonetheless made major contributions to background work, debate and discussion are Dr Giuliano Bonoli, Dr Anne Daguerre, Mr Benoît Gay-des-Combes, Professor Olli Kangas and Professor Hellmut Wollmann, and we are grateful for their support.

Peter Taylor-Gooby Kent, December 2004 


\section{Notes on the Contributors}

Ana Arriba is a postdoctoral researcher with the Spanish National Research Council (UPC-CSIC) in Madrid. She has been lecturer at the Universities of Salamanca and Complutense de Madrid. Publications include: Pobres o excluídos? El Ingreso Madrileño de Integración en perspectiva comparada (with Serrano, A.), Fundación Argentaria-Ministerio de Trabajo y Asuntos Sociales, 1998 and 'Spain: Poverty, Social Exclusion and "Safety Nets"' with Luis Moreno in M. Ferrera (ed.), Welfare State Reform in Southern Europe, Routledge, 2005.

Andreas Aust is a self-employed social scientist, currently participating in a research project on 'Working Society and Industrial Democracy in Europe' conducted by the University of Vienna (www.noderesearch.at/lp.php?id=243). Publications include: 'Konjunktur und Krise des Europäischen Sozialmodells: ein Beitrag zur politischen Präexplantationsdignostik', with S. Leitner and S. Lessenich, Politische Vierteljahresschrift, 2002 and 'From "Eurokeynesianism" to the "Third Way": the Party of European Socialists and European Employment Policies', in G. Bonoli and M. Powell (eds.), Social Democratic Party Politics in Contemporary Europe, Routledge, 2003.

Frank Bönker is Assistant Professor at the Department of Economics, European University Viadrina, Frankfurt (Oder) and Research Fellow at theFrankfurt Institute for Transformation Studies. He has written a substantial number of publications on post-communist economic transformation and social service and welfare state reform in Germany.

Johannes Kananen is a Research Assistant on the project Welfare Reform and the Management of Societal Change at the University of Kent. His publications include 'Rakenteellinen työttomyys ja työmarkkinakysymys [Structural Unemployment and the Labour Market Question]', with P. Kananen, Työpoliittinen aikakauskirja, vol 45(3): 52-71, Ministry of Labour, Helsinki.

Trine P. Larsen is a Research Assistant on the project 'Welfare Reform and the Management of Societal Change' at the University of Kent. Recent publications include a report to the European Commission 
Multi-career Families, Work and Care in Finland, France, Portugal, Italy and the UK; a chapter on 'New Risks at the EU Level' in P. Taylor Gooby (ed.) New Risks, New Welfare; and an article: 'Work and care strategies of European families', Social Policy and Administration, vol 38, 2004.

Luis Moreno is Senior Research Fellow at the Spanish National Research Council, CSIC, in Madrid. Recent publications include: The Territorial Politics of Welfare, Routledge, 2005; 'Spain's Transition to New Risks: A Farewell to Superwomen', in P. Taylor-Gooby (ed.), New Risks, New Welfare. The Transformation of the European Welfare State, Oxford University Press, 2004; 'Mending nets in the South. Anti-poverty policies in Greece, Italy, Portugal and Spain' (with M. Matsaganis, M. Ferrera L. Capucha), Social Policy and Administration, 2003; 'Europeanisation, Mesogovernments and Safety Nets', European Journal of Political Research, 2003; and The Federalisation of Spain, Frank Cass, 2001.

Bruno Palier is CNRS researcher in Centre d'Études de la Vie Politique Française (CEVIPOF), Paris. His research interest is in welfare state reform from a French and a comparative perspective. He was a member of the Management Committee of Cost A15, 'Reforming Welfare Systems in Europe' and was responsible for the MIRE programme 'Comparing Social Welfare Systems in Europe'. Recent publications include: co-editor with Ana Guillen of the special issue of Journal of European Social Policy on 'EU accession, Europeanisation and social policy', (2004, vol 14 no 3), co-editor with Nick Manning of Global Social Policy, vol 3, no 2, 2003, 'Globalisation, Europeanisation and the Welfare State'; 'Facing Pension Crisis in France', in Noel Whiteside and Gordon Clarke, Pension Security in the 21st Century: Redrawing the PublicPrivate Divide, Oxford University Press, 2003; Gouverner la Sécurité Sociale, PUF, 2002; Globalisation and European Welfare States: Challenges and Changes, edited with R. Sykes and P. Prior, Palgrave, 2001; and 'Defrosting the French Welfare State', West European Politics, vol 23, no 2, 2000 .

Peter Taylor-Gooby in Professor of Social Policy at the University of Kent and directs the ESRC Social Contexts and Responses to Risk network. Recent publications include: Making a European Welfare State? (edited), Blackwell, 2003; European Welfare States under Pressure (edited), Sage, 2001; European Welfare Futures (with Vic George and Giuliano Bonoli) Polity, 2000; The End of the Welfare State? (with Stephan Svallfors) 
Routledge, 1999; Risk, Trust and Welfare (edited), Macmillan, 2000 and Choice and Public Policy (edited), Macmillan, 1998.

Virpi Timonen is Lecturer in Social Policy and Ageing at the Department of Social Studies, Trinity College Dublin. She has previously worked in the Department of Social Policy, University of Turku, and is the author of Restructuring the Welfare State, Edward Elgar, 2003. She has also written a range of journal articles, reports and book chapters on welfare state restructuring in the Nordic welfare states and on social policy in Ireland. 